\title{
Продовольственные заготовки в Центрально-Черноземном районе в годы Первой мировой войны (1914-1917)
}

\author{
Оськин М.В. \\ Международная полицейская академия ВПА, \\ 300025, Россия, г. Тула, ул. Рязанская, 1 \\ E-mail: maxozv@yandex.ru
}

\begin{abstract}
Аннотация. Одной из важнейших задач власти в период Первой мировой войны стало снабжение армии и фронта продовольствием и фуражом. Центрально-Черноземный регион, расположенный в центре России, рядом с второй столицей империи - Москвой, должен был взять на себя обязанности по снабжению как фронта, так и тыловых потребляющих районов. Большую часть хлеба воюющей России поставляли малороссийские и поволжские регионы. Однако значение великороссийских черноземных губерний нельзя переоценить - с наступлением продовольственного кризиса именно они работали на снабжение старой столицы Москвы и расположенного в Белоруссии Западного фронта. С расширением номенклатуры централизованных заготовок продуктов питания и нарастания транспортных затруднений роль Центральной России в деле снабжения еще более возросла.
\end{abstract}

Ключевые слова: продовольственное снабжение, Центрально-Черноземный район, Министерство земледелия, хлебная разверстка, заготовки продовольствия, продфураж.

Для цитирования статьи: Оськин М.В. 2021. Продовольственные заготовки в ЦентральноЧерноземном районе в годы Первой мировой войны (1914-1917). Via in tempore. История. Политология. 48 (4): 859-870. DOI: 10.52575/2687-0967-2021-48-4-859-870.

\section{The food procurement in the Central-Chernozem district during the First World War (1914-1917)}

\author{
Maxim V. Os` kin \\ WPA International, Police Academy \\ 1, Ryazanskaya St., Tula, Russia, 300025 \\ E-mail:maxozv@yandex.ru
}

\begin{abstract}
One of the most important tasks of the government during the First World War was to supply the army and the front with food and fodder. Food-producing regions played a leading role in this task. One of these economic districts was the Central-Chernozem district, located South of Moscow. Most of the bread of the warring Russia was supplied by the little Russian and Volga regions. The entire set of food products for the army - bread, meat, vegetables, fats, sugar - was supplied by the Central Black Earth region due to the diversity of its geography. If the northern provinces specialized in oats, the southern ones gave vegetable oils. However, the significance of the great Russian black earth provinces cannot be overestimated - with the onset of the food crisis, they worked to supply the old capitalMoscow, and the Western front located in Belarus. With the expansion of the range of centralized food supplies and increasing transport difficulties, the role of Central Russia in the supply chain has increased even more. The gradual transition of the procurement policy to fixed prices and centralized planning took into account the surpluses of all types of food products. The proximity of the Central Chernozem region to the front lines suggested that the military authorities would purchase some of the products themselves, bypassing the structures of the Ministry of Agriculture. In 1917, almost all food was subject to the state monopoly, since the country, exhausted by the war, now supplied all raw materials to the front.
\end{abstract}


Keywords: food supply, Central-Chernozem district, Ministry of agriculture, grain distribution, food procurement, food storage.

For citation: Os' kin M.V. 2021. The food procurement in the Central-Chernozem district during the First World war (1914-1917). Via in tempore. History and political science. 48 (4): 859-870 (in Russian). DOI: $10.52575 / 2687-0967-2021-48-4-859-870$.

\section{Введение}

Актуальность исследования российской истории периода поздней империи во многом определяется самим фактом революционного крушения государственности, а значит, осмыслением причин произошедшего. В годы Первой мировой войны 1914-1918 гг. важным вопросом, от решения которого зависел ход вооруженного конфликта, стал продовольственный, выдвинувшийся на первое место в комплексе проблем, с которыми столкнулась Россия в военное время, в силу его всеобъемлющего влияния на жизнь воюющей страны. Продовольственный вопрос неизменно является важным звеном в цепи функционирования общественных и государственных институтов.

В связи с этим анализ переломного периода в истории России, когда этот вопрос сыграл одну из ведущих ролей в надломе российской государственности и смене политического строя, несомненно, отличается новизной своего исследования. Использование принципа историзма позволяет выстроить причинно-следственную цепь действий государства в продовольственной политике периода войны, показать усилия избранного региона в процессе снабжения, вариативность в преодолении трудностей военного времени в отношении продовольственного вопроса.

Изучение состояния продовольственного снабжения в России в период Первой мировой войны на примере Центрально-Черноземного района является целью настоящей статьи. Район «старого земледелия» внес существенный вклад в состояние продовольственного вопроса в стране. Экономическое районирование российских губерний имело два основных вида - потребляющие (которым не хватало собственного хлеба) и производящие (дающие хлеб соседям). Последние играли свою роль и в хлебном экспорте.

В свою очередь, в годы войны армия требует широкой номенклатуры продовольствия, постепенно расширяющейся по мере истощения продовольственных ресурсов воюющей страны. Такие задачи требовали централизованной государственной политики, которая в России в период Первой мировой войны выполнялась Министерством земледелия. Все имевшиеся излишки продовольственной продукции спустя год после начала войны стали учитываться государством, подлежали передаче ему по твердым ценам, а в 1917 г. перешли под действие реквизиционного права.

Разумеется, производящие губернии играли в продовольственной политике государства и общества большую роль, нежели потребляющие. Во-первых, более разнообразной была номенклатура поставляемого для нужд фронта и тыла продовольствия. Во-вторых, излишками требовалось делиться с соседями - потребляющими губерниями. В-третьих, сельскохозяйственные производители снабжали не только армию, но и города своей области. Таким районом был и Центрально-Черноземный, включавший в себя весьма отличавшиеся друг от друга по количеству продовольственных излишков Воронежскую, Курскую, Орловскую, Рязанскую, Тамбовскую и Тульскую губернии (хотя в историографии Тульская и Рязанская могут исключаться из данного района [Безгин, 2004, с. 4]).

\section{Результаты и их обсуждение}

Первым и главным продуктом армии и населения являлся хлеб. ЦентральноЧерноземный район имел свои особенности в хлебном производстве, специализируясь на ржи и овсе (исключение составляла Воронежская губерния, где были значительные посе- 
вы пшеницы). Рожь - первый продукт для войск, овес - лучший корм для конского состава действующей армии. Поэтому район работал прежде всего на заготовку хлеба для армии, равно как и на снабжение Москвы и столичного промышленного региона в целом.

Экспорт ржи и овса до войны был небольшим - около 80 млн пудов, почему армия постепенно стала выбирать не только экспортный излишек, образующийся от приостановки хлебного экспорта, но и часть той продукции, что до войны шла на внутренний рынок. Значение Центрально-Черноземного района заключалось в том, что здесь сосредоточивалось 3/5 всего экспортного избытка овса (до 20 млн пудов), требовавшегося для лошадей. Армия требовала более 100 млн пудов зернового фуража, а постепенно - и еще больше, но на первом этапе войны овес закупался преимущественно в Центральном Черноземье.

Примечательно, что в Центрально-Черноземном районе излишек продовольственного хлеба (рожь и пшеница) имели всего три губернии из шести - Тамбовская, Воронежская и Курская (если считать подушевое годичное потребление хлеба в 13 пудов). Справедливо мнение, что «ситуация в Центральном районе страны была двойственной: Курская, Тамбовская, Воронежская губернии имели избыток хлебов, тогда как в соседних Орловской, Тульской, Рязанской хлеба было недостаточно» [Тагирова, 2014, с. 66]. Следовательно, даже внутри района губернии должны были делиться друг с другом хлебом, пусть и в относительно небольших количествах ${ }^{134}$ (см. Таблицу 1).

Таблица 1

Table 1

Остаток хлеба на душу населения (в пудах) по данным Министерства земледелия

The remaining bread per capita (in pounds) according to the Ministry of Agriculture

\begin{tabular}{|l|l|l|l|}
\hline \multicolumn{1}{|c|}{ Губерния } & Средний в 1910-1914 гг. & \multicolumn{1}{|c|}{ В 1914 г. } & Предполагаемый в 1915 г. \\
\hline Воронежская & 20,66 & 20,00 & 25,88 \\
Курская & 20,38 & 17,61 & 18,87 \\
Орловская & 12,37 & 9,47 & 11,46 \\
Рязанская & 12,16 & 10,62 & 10,30 \\
Тамбовская & 21,20 & 21,76 & 22,78 \\
Тульская & 13,23 & 9,01 & 12,11 \\
\hline
\end{tabular}

Орловская, Рязанская и Тульская губернии имели излишки главного фуражного продукта, закупаемого армией для конского состава войск - овса, что в военный период побуждало землевладельцев расширять зернофуражный клин в посеве [Хрящева, 1921, c. 29]. В то же время Воронежская, Тамбовская и Курская губернии прежде всего поставляли продовольственный хлеб для людей, имея избытки в 13,5 млн пудов для Тамбовской губернии, 23,7 млн - для Воронежской и 8,3 млн - для Курской [Островский, 1999, с. 483]. Одна только Тамбовская губерния выращивала до 120 млн пудов зерна, из которых 50 млн шло на рынок в другие регионы [Алехина и др., 2010, с. 99]. Между тем, в отличие от соседей по экономическому району, Тульская и Рязанская губернии и до войны «находились в зоне голода» без дополнительных закупок в южных районах [Нефедов, 2010, с. 519].

Кроме того, в середине войны данный экономический район оказался разделенным по военным обстоятельствам. В 1916 г. Курская губерния вошла в тыловой район ЮгоЗападного фронта, а западные уезды Орловской (Брянский, Трубчевский, Карачевский, Севский и Дмитровский) - в тыл Западного фронта, что позволило военным фуражирам самостоятельно производить здесь закупки продовольствия и фуража. Следовательно, продукция этих местностей, по сути, находилась скорее в распоряжении военных властей, нежели отвечавшего за продовольственное дело в империи Министерства земледелия и его уполномоченных.

${ }^{134}$ Российский государственный военно-исторический архив (далее РГВИА). Ф. 499. Оп. 3. Д. 1366. Л. 206. 
Осенью 1915 г., когда стало ясно, что война затягивается на неопределенный период, а хлебное снабжение городов было уже нарушено [Нефедов, 2005, с. 117], государство перешло к политике твердых цен, так как основная часть финансов уходила на военные нужды. Твердые цены, постепенно вводимые на разные виды продовольственной продукции министром земледелия А.Н. Наумовым и первоначально распространявшиеся лишь на закупки для армии, в первую голову затронули хлеб. Соответственно, регионы страны стали получать разнарядку на поставку хлеба - требовавшееся количество распределялось среди уполномоченных Министерства земледелия соразмерно расчетным цифрам полученного урожая и закупалось ими.

Первая такая разнарядка прошла для продукции урожая 1915 г., которая должна была обеспечить кампанию 1916 г., в том числе и Брусиловский прорыв. Основным хлебом Центрально-Черноземного района являлись рожь и овес (ячмень, посевы которого были незначительны, не закупался вовсе, а пшеница - только в Воронежской губернии) ${ }^{135}$ (см. Таблицу 2).

Таблица 2

Table 2

Размеры заготовки хлебов для армии из урожая 1915 г. (тыс. пудов / в \% к сбору 1915 г.)

The size of the preparation of bread for the army from the harvest of 1915 (thousand pud / \% of the collection of 1915)

\begin{tabular}{|l|l|l|l|l|l|}
\hline \multicolumn{1}{|c|}{ Губерния } & \multicolumn{1}{c|}{ Рожь } & \multicolumn{1}{c|}{ Пшеница } & \multicolumn{1}{c|}{ Овес } & \multicolumn{1}{|c|}{ Просо } & \multicolumn{1}{c|}{ Гречиха } \\
\hline Воронежская & $3000 / 5,3$ & $100 / 0,3$ & $3500 / 15,3$ & $750 / 6,5$ & $50 / 2,2$ \\
Курская & $2900 / 6,1$ & - & $5000 / 18,2$ & $175 / 3,4$ & $800 / 16,3$ \\
Орловская & $800 / 2,4$ & - & $5500 / 19,2$ & $60 / 2,8$ & $60 / 4,8$ \\
Рязанская & $600 / 2,0$ & - & $2000 / 8,9$ & $60 / 1,8$ & $60 / 14,3$ \\
Тамбовская & $7000 / 9,4$ & - & $12000 / 26,7$ & $750 / 4,9$ & $50 / 14,7$ \\
Тульская & $500 / 1,9$ & - & $7000 / 32,1$ & $50 / 16,1$ & $50 / 9,3$ \\
\hline
\end{tabular}

В 1916 г. была проведена сельскохозяйственная перепись, дабы определить возможности России к продолжению войны в продовольственном отношении. Предварительные данные о сборе и остатке за посевом озимых хлебов в 1916 г., собранные Министерством земледелия, показали, что сбор хлебов выше среднего за 1911-1915 гг. наблюдался во всем Центральном Черноземье, дававшем продовольственный хлеб, - Воронежской, Курской, Орловской и Тамбовской губерниях. В Рязанской губернии сбор был средним, и лишь Тульская дала хлебов ниже среднего ${ }^{136}$. Сокращение сбора хлебов в Нечерноземье побуждало усилить их снабжение за счет черноземных регионов, увеличивая объемы поставок в 2,5 раза, что само по себе являлось невыполнимым [Анфимов, 1962, с. 311, 313].

Когда выяснилось, что урожай 1916 г. ниже среднего за последнее пятилетие не менее чем на 400 млн пудов, государство постаралось поставить на учет для последующего изъятия весь возможный хлеб. Причем его перераспределение должно было играть высокую роль, дабы потребляющие губернии и города также получили хлеб. Расчеты Министерства земледелия базировались на цифрах вероятного остатка хлеба от урожая 1916 г. (для Центрально-Черноземного района) ${ }^{137}$ (см. Таблицу 3).

Примечательно, что эта ведомость, представлявшая действительность в преувеличенном масштабе, была опубликована лишь 22 сентября 1917 года. Однако, исходя из этих цифр, министр земледелия А.А. Риттих составил план хлебной разверстки зимы 1917 г., требовавшей передачи государству всего требовавшегося для него хлеба, так как для полного удовлетворения потребностей государство должно было ежемесячно иметь около 91 млн пудов зернофуража [Кондратьев, 1993, с. 91].

${ }^{135}$ РГВИА. Ф. 369. Оп. 12. Д. 28. Л. 1-5.

${ }^{136}$ Государственный архив Российской Федерации (далее ГА РФ). Ф. 1796. Оп. 1. Д. 67а. Л. 1.

${ }^{137}$ РГВИА. Ф. 499. Оп. З. Д. 1393в. Л. 225-240. 
Вероятный остаток хлеба урожая 1916 г. (в пудах) The probable remainder of the bread harvest of 1916 (in pud)

\begin{tabular}{|l|l|l|l|l|l|}
\hline \multicolumn{1}{|c|}{ Губерния } & \multicolumn{1}{c|}{$\begin{array}{c}\text { Рожь } \\
\text { в зерне }\end{array}$} & \multicolumn{1}{c|}{$\begin{array}{c}\text { Пшеница } \\
\text { в зерне }\end{array}$} & \multicolumn{1}{c|}{$\begin{array}{c}\text { Ячмень } \\
\text { в зерне }\end{array}$} & \multicolumn{1}{c|}{$\begin{array}{c}\text { Овес } \\
\text { в зерне }\end{array}$} & \multicolumn{1}{c|}{$\begin{array}{c}\text { Весь хлеб } \\
\text { в зерне }\end{array}$} \\
\hline Воронежская & 16345653 & 6430008 & 1651639 & 5043930 & 29471230 \\
Курская & 18229106 & 2537857 & 258581 & 10215737 & 31241281 \\
Орловская & 15167975 & 105721 & 59490 & 7403917 & 22737103 \\
Рязанская & 9615375 & 26547 & 31 & 5323522 & 14965475 \\
Тамбовская & 27028938 & 159094 & 3780 & 9099728 & 36291540 \\
Тульская & 11181726 & 46719 & 890 & 6313360 & 17542695 \\
\hline
\end{tabular}

Как известно, разверстка оказалась непосильной для большинства регионов России в связи с тем, что «правительство оказалось не в состоянии пропорционально распределить хлебные наряды по губерниям с учетом их потенциальных экономических возможностей» [Магомедов, Гришакова, 2012, с. 67], дав к лету 1917 г. лишь около 2/3 затребованного хлеба. Но хлеб требовался стране немедленно ввиду падения государственных хлебных запасов, и потому разверстка включала в себя все виды хлебов, даже пусть производство их в том или ином районе было минимальным. Министр земледелия А.А. Риттих упрекал в слабом поступлении хлеба по разверстке воронежского, курского, рязанского и тульского уполномоченных; в средней группе по выполнению оказался орловский уполномоченный, и лишь тамбовский уполномоченный получил лестную оценку [Мацузато, 1997, с. 168]. Отвечавшие за выполнение разверстки губернаторы подключали силовой ресурс, порой требуя при «необходимости оказывать всякое, в том числе силовое содействие в деле реквизиции свободных остатков хлеба у частных владельцев и крестьян» [Курская губерния, 2014, с. 71].

Всего Центрально-Черноземный район давал лишь около 190 млн пудов хлебов. Но, во-первых, были подключены все губернии без исключения (даже Рязанская, где вследствие тяжелейшей продовольственной ситуации ${ }^{138}$ не закупали ржи, но только корма - овес, и где дело дошло до жалоб непосредственно в Ставку Верховного командования, то есть самому императору). Во-вторых, размер разверстки в большинстве превзошел преувеличенные сведения об излишках от урожая 1916 г., что на практике вело к недоснабжению городов района. Притом лишь две губернии - Воронежская и Тамбовская давали львиную долю продовольственного хлеба, и даже Курская губерния сосредоточилась на овсе и гречихе, что показывает степень падения производства и резкого снижения запасов хлеба в связи с военными реквизициями.

Считалось, что в 1917 г. Центрально-Черноземный район должен был иметь не менее 60 млн пудов хлебного избытка ${ }^{139}$, но дальнейшее падение сельскохозяйственного производства в 1917 г. еще более снизило возможности России по удовлетворению нужд потребителей в ситуации мировой войны. Если риттиховская разверстка рассчитывала на около 110 млн пудов продовольственного хлеба и крупы в Центрально-Черноземном районе, то Министерство продовольствия Временного правительства по расчетам урожая 1917 г. вдвое снизило эту цифру ${ }^{140}$ (см. Таблицу 4).

${ }^{138}$ Государственный архив Рязанской области. Ф. 5. Оп. 2. Д. 2998. Л. 12об.; РГВИА. Ф. 2005. Оп. 1. Д. 81. Л. 244.

139 Урожай хлебов в России в 1917 г. М., 1918. С. 36.

140 Экономическое положение России накануне Великой Октябрьской социалистической революции. Документы и материалы. Март - октябрь 1917 г. Л., 1967. Ч. 3. С. 451. 
Сбор хлебов в 1917 г. по данным Министерства продовольствия (в тыс. пудов) Grain harvest in 1917 according to the Ministry of Food (in thousand pud)

\begin{tabular}{|l|l|l|l|}
\hline \multicolumn{1}{|c|}{ Губерния } & \multicolumn{1}{c|}{$\begin{array}{c}\text { Избыток } \\
\text { продовольственных и } \\
\text { крупяных хлебов }\end{array}$} & $\begin{array}{c}\text { Избыток или } \\
\text { недостаток кормовых } \\
\text { хлебов }\end{array}$ & $\begin{array}{c}\text { Общий сбор } \\
\text { хлебов }\end{array}$ \\
\hline Курская & +12600 & +2200 & 81296 \\
Орловская & +11800 & +2500 & 67389 \\
Тульская & +4200 & +2900 & 46993 \\
Рязанская & - & -800 & 47141 \\
Тамбовская & +16000 & -500 & 95651 \\
Воронежская & +13000 & -10500 & 84473 \\
Итого по району & +57600 & -4200 & 422943 \\
\hline
\end{tabular}

Временное правительство пыталось спасти положение дел опорой на кооперативы, в войну работавшие в тесной связи с земствами [Петровичева, 2001, с. 39], и государственной монополией на всю продовольственную продукцию. Однако «в условиях распада народного хозяйства, дезорганизации транспорта и острого продовольственного кризиса монополия торговли хлебом не могла спасти создавшегося в стране положения» [Дихтяр, 1960, с. 222]. Скорее наоборот, она подтолкнула развитие спекуляции и придерживание продукции хлебодержателями. Преодолеть развал народного хозяйства не удалось, что и далее усиливало радикализм революционного процесса, в деревне характеризующийся как «аграрный саботаж» [Люкшин, 2013, с. 245]. Неутешительный итог хлебной ситуации в Центрально-Черноземном районе к концу войны был подведен незадолго до октябрьского переворота. Четыре губернии из шести - из производящих (именно такое положение вещей рисовали цифры разверстки) - оказались в разряде потребляющих ${ }^{141}$ (см. Таблицу 5).

Таблица 5

Table 5

Валовый сбор ржи и пшеницы в 1917 г. и потребность в них у населения на 1917-1918 гг. (в тыс. пудов)

The gross harvest of rye and wheat in 1917 and the need for them among the population for 1917-1918 (in thousands of pud)

\begin{tabular}{|l|l|l|}
\hline \multicolumn{1}{|c|}{ Губерния } & Потребности населения & Валовый сбор в 1917 г. \\
\hline Курская & 46874 & 41786 \\
Орловская & 38708 & 42632 \\
Тульская & 29692 & 28265 \\
Рязанская & 36000 & 30004 \\
Тамбовская & 57336 & 61138 \\
Воронежская & 57736 & 56946 \\
\hline
\end{tabular}

Вторым по важности продуктом для питания армии являлось мясо. Для войск в первые два года войны закупался крупный рогатый скот (ввиду незначительного количества рефрижераторных вагонов, большая часть мяса поставлялась фронту в живом виде) мясной паек солдата, и свинина - жировой паек. В поставках последнего продукта огромную роль играло как раз Центральное Черноземье, так как $90 \%$ всего экспорта свиней приходилось на 7 губерний, в том числе Воронежскую, Курскую и Орловскую [Островский, 2014, с. 337].

${ }^{141}$ Российский государственный архив экономики (далее РГАЭ). Ф. 1943. Оп. 4. Д. 222. Л. 7. 
В первые полтора года войны скот для армии в тылу покупался в небольших количествах и исключительно товарный излишек, так как войсками активно использовался скот прифронтовых районов. В ходе Великого отступления русской армии в апреле - сентябре 1915 г. скот Польши, Литвы, Белоруссии и Галиции эвакуировался в тыловые районы фронтов, ввиду чего этого скота хватило для питания войск вплоть до конца зимы 1915-1916 гг.

Что касается жиров, то, помимо свинины, в армию поставлялось и сливочное масло (преимущественно из Сибири). Сала для полного удовлетворения войск не хватало, почему к его закупкам были подключены все возможные регионы. В Центрально-Черноземном районе свинину поставляли Воронежская, Курская, Рязанская и Тамбовская губернии как имевшие излишки продукции по данным военно-ветеринарного управления ${ }^{142}$.

Истощение эвакуированного запаса скота к весне 1916 г. вынудило Министерство земледелия перейти к централизованным закупкам мяса для армии, как это ранее уже было сделано в отношении хлебной продукции. На 1916 г. была составлена примерная разверстка поставки крупного рогатого скота ${ }^{143}$ (см. Таблицу 6).

Таблица 6

Table 6

Размеры поставки скота для фронта в 1916 г. по Центрально-Черноземному району The size of the supply of livestock for the front in 1916 in the Central Chernozem region

\begin{tabular}{|l|l|l|l|l|}
\hline \multicolumn{1}{|c|}{ Губерния } & \multicolumn{1}{|c|}{$\begin{array}{c}\text { Голов в } \\
\text { наличии }\end{array}$} & $\begin{array}{c}\text { Число голов } \\
\text { на } 100 \text { жителей }\end{array}$ & $\begin{array}{c}\text { Определено голов } \\
\text { к поставке в 1916 г. }\end{array}$ & $\begin{array}{l}\text { \% от общего } \\
\text { количества }\end{array}$ \\
\hline Орловская & 396025 & 15 & 30000 & 7 \\
Тульская & 323994 & 17 & 20000 & 5 \\
Тамбовская & 612396 & 17 & 60000 & 10 \\
Рязанская & 414264 & 15 & 20000 & 5 \\
Курская & 490473 & 15 & 25000 & 5 \\
Воронежская & 781324 & 22 & 80000 & 10 \\
По 37 регионам & 27331713 & & 3288000 & \\
Европейской России & & & & \\
\hline
\end{tabular}

Следует заметить, что поставка скота производилась более равномерно, нежели хлебные закупки. Если большая часть российских регионов требовала хлеба для ввоза, что накладывало обязательства по поставкам только на производящие губернии, то скот у крестьян и землевладельцев имелся во всех губерниях, почему скот закупался по намеченной квоте. Тем не менее потеря коровы могла ударить по крестьянскому хозяйству куда сильнее, нежели хлебная поставка.

Поэтому, дабы более справедливо распределить поставку животных, закупки производились земствами, исходя из цифры, требуемой Министерством земледелия. Притом, чтобы не вносить рознь в деревенский социум, поставки распространялись и на помещичье стадо, нередко состоявшее из ценного племенного скота, почему владельцы получили право заменять его (то есть покупать обычных коров у крестьян и поставлять их взамен племенных животных ценных пород по распределению) ${ }^{144}$ (см. Таблицу 7).

Как видно из таблицы 7, в Центральном Черноземье основным поставщиком свиней стала Тамбовская губерния, а овец - Воронежская. Закупка свиней на сало оказалась минимальной, так как крестьяне предпочитали продавать этот продукт в города, где чаще всего не хватало и растительных жиров. То есть определенная внутрирайонная специализация существовала и в данном вопросе.

\footnotetext{
${ }^{142}$ РГВИА. Ф. 369. Оп. 12. Д. 2. Л. 255 об.

${ }^{143}$ ГА РФ. Ф. 1783. Оп. 2. Д. 370. Л. 2-4.

${ }^{144}$ ГА РФ. Ф. 1783. Оп. 2. Д. 370. Л. 4-5.
} 
Закупка скота земствами и областными организациями с 1 апреля по 1 ноября 1916 г.

Purchase of livestock by zemstvos and regional organizations from April 1 to November 1, 1916

\begin{tabular}{|l|l|l|l|l|}
\hline \multicolumn{1}{|c|}{ Губерния } & \multicolumn{1}{|c|}{$\begin{array}{c}\text { Крупный } \\
\text { рогатый скот }\end{array}$} & \multicolumn{1}{|c|}{ Овцы } & \multicolumn{1}{|c|}{ Свиньи } & $\begin{array}{c}\text { Всего скота при пересчете } \\
\text { на крупный рогатый скот }\end{array}$ \\
\hline Орловская & 7657 & 64976 & 7 & 15782 \\
Тульская & 14077 & 277 & 7 & 14115 \\
Тамбовская & 43254 & 42100 & 2655 & 49843 \\
Рязанская & 24007 & 8060 & 137 & 25083 \\
Курская & 27279 & 8659 & - & 28361 \\
Воронежская & 65171 & 165853 & 185 & 85996 \\
Всего по 37 губерниям & 2424284 & 2161456 & 33657 & 2610923 \\
\hline
\end{tabular}

Установление твердых цен на скот летом 1916 г. означало, что в перспективе скот будет изыматься у населения по разверстке. Земства уже не справлялись с покупкой, так как добровольная продажа упала, ибо «щены на мясные продукты не возмещали полностью ущерба от потери скота... Потому практически с самого начала войны на мясо и мясопродукты цены были фиксированными, и как только заканчивались закупки, они сразу же подскакивали» [Самохин, 2002, с. 451], а рост однокоровных крестьянских хозяйств (единственная корова не подлежала реквизиции) уменьшил доступность закупки ${ }^{145}$ (см. Таблицу 8).

Таблица 8

Table 8

Разверстка скота на январь-февраль 1917 г. (в пудах)

Distribution of livestock for January-February 1917 (in pud)

\begin{tabular}{|l|l|l|}
\hline \multicolumn{1}{|c|}{ Губерния } & Мясо крупного рогатого скота и свиней & \multicolumn{1}{c|}{ Свиное сало } \\
\hline Воронежская & 60252 & 18408 \\
Курская & 78520 & 18022 \\
Орловская & 161210 & 19548 \\
Рязанская & 141372 & 13610 \\
Тамбовская & 131962 & 17836 \\
Тульская & 69710 & 8916 \\
\hline
\end{tabular}

Поставка мяса и сала в 1917 г. исходила не из наличного излишка животных, так как такового практически не было, а из требований Министерства земледелия. После Февральской революции Временному правительству, разумеется, не удалось добиться требуемой поставки ${ }^{146}$ (см. Таблицу 9).

Таблица 9

Table 9

Ведомость выполнения губерниями нарядов на мясо и сало в 1917 г. (в пудах) Statement of the execution of orders for meat and lard by the provinces in 1917 (in pounds)

\begin{tabular}{|l|l|l|l|l|}
\hline \multicolumn{1}{|c|}{ Губерния } & Наряд на мясо & Поставлено мяса & Наряд на сало & Поставлено сала \\
\hline Воронежская & 1588200 & 1106697 & 136600 & 144443 \\
Курская & 250376 & 157073 & 133700 & 6407 \\
Орловская & 118700 & 256766 & 145000 & 11329 \\
Рязанская & 486200 & 177498 & 101000 & 3055 \\
Тамбовская & 823400 & 407224 & 132304 & 12881 \\
\hline
\end{tabular}

${ }^{145}$ ГА РФ. Ф. 6809. Оп. 1. Д. 68. Л. 65-67.

146 РГАЭ. Ф. 1943. Оп. 3. Д. 21. Л. 2. 
Все районы в той или иной степени провалили правительственное задание, однако Орловская губерния вдвое перевыполнила план по скоту. В связи с массированной закупкой скота, вызвавшей сопротивление скотовладельцев, и нарастанием нехватки мяса для населения Министерство продовольствия пыталось частично компенсировать его рыбой (рыба поставлялась армии, но ввиду ее быстрой порчи объемы были сравнительно невелики) ${ }^{147}$.

Помимо хлеба и мяса, внутри страны для нужд армии, а затем и населения потребляющих регионов закупались овощи (в сушеном и сыром виде). Причем с осени 1916 г., когда явственно обозначился продовольственный кризис, уполномоченные стали покупать даже «второй хлеб» - картошку, потребление которой позволяло ликвидировать продовольственный дефицит в деревне [Островский, 2013, с. 278], не говоря о противоцинготной продукции (лук, чеснок) и квашеной капусте. Заготовки картофеля производились во всем Центральном Черноземье, за исключением Рязанской губернии ${ }^{148}$, а капусты в Орловской, Тамбовской и Тульской ${ }^{149}$. Воронежская губерния являлась лидером в поставках репчатого лука среди всех регионов империи (300 тыс. пудов на 1917 г.), а Курская - одним из основных поставщиков чеснока ${ }^{150}$. В 1917 г. все губернии Центрального Черноземья участвовали в заготовках овощей для армии и населения.

Воронежская и Тамбовская губернии с 1916 г. стали поставщиками подсолнечного масла (пусть и в небольшом количестве), которым, ввиду нехватки традиционных жиров, в фронтовом тылу стали заменять сало и сливочное масло. Например, с 1 сентября 1916 по 15 мая 1917 г. в распоряжение воронежского уполномоченного с масличных заводов поступило 860500 пудов подсолнечного масла ${ }^{151}$. Также весь район поставлял действующей армии сахар (с начала войны) и с 1917 г. - яйца. Прежде всего - те же Воронежская и Тамбовская губернии, наряду с Казанью и Ярославлем являвшиеся центрами яичного производства еще перед войной [Томстон, 2008, с. 30].

Из фуражного продукта, помимо овса, Центрально-Черноземный район работал на производстве сена, причем Рязанская губерния отправляла его исключительно в Москву, чтобы «предоставить возможность другим сенным губерниям работать непосредственно на фронт». По той же причине сено Тульской губернии закупалось Земским Союзом, а в Орловской (за исключением северных Севского и Трубчевского уездов) и Курской (кроме уездов, смежных с харьковским регионом) сено почти не закупалось ввиду распаханности территории ${ }^{152}$. Из 151 млн пудов сена на 1917 г. Воронежская губерния должна была дать 2 млн, Тамбовская - 3 млн пудов. Для нужд Москвы 2 млн пудов должны были поставить Московская и Тульская губернии, а также 5,2 млн - Рязанская ${ }^{153}$.

\section{Заключение}

Таким образом, в годы Первой мировой войны Центрально-Черноземный район Российской империи внес существенный вклад в продовольственные усилия страны по снабжению действующей армии и населения производящих губерний. В черноземной деревне вплоть до 1917 г. поддерживался довоенный уровень производства, что и позволило выполнять государственные поставки вплоть до хлебной разверстки [Иванов, 2002, с. 138]. В период развития продовольственного кризиса, особенно накануне революции и в 1917 г., район играл огромную роль в поддержании сравнительно сносного продовольственного баланса в Центральной России, питая промышленность, города и потребляю-

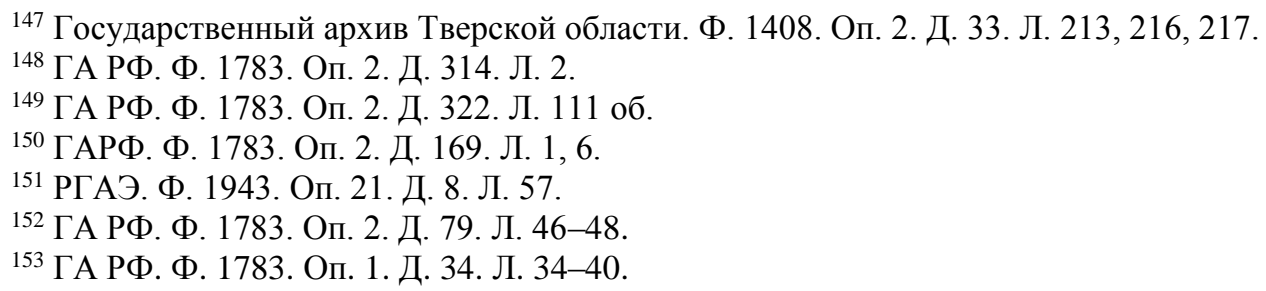


щую деревню Центрально-Промышленного района, в то время когда государственные запасы хлеба падали от месяца к месяцу.

В районе закупалась вся требовавшаяся для фронта номенклатура продуктов питания (за исключением рыбы и сливочного масла), хотя ни по одному из видов продукции район не имел решающего значения в сравнении с более хлебными (Новороссия и Поволжье) или скотоводческими (Юг и Зауралье) районами. Именно поэтому круг лиц, отвечавших за поставки продовольствия и фуража, постоянно расширялся, а под руководством уполномоченных Особого Совещания по продовольственному делу создавались новые направления деятельности.

Помимо собственно армии, Центрально-Черноземный район непосредственно питал вторую столицу - Москву, где ситуация с нарастанием продовольственных затруднений лишь осложнялась. До войны столичный район снабжался хлебом не только и не столько из близлежащих, а скорее из отдаленных регионов империи [Роднов, 2012, с. 202]. Теперь же эти регионы работали на обеспечение потребностей армии и промышленности Урала. Для столичного региона Центрально-Черноземный район являлся ближайшим резервом, где москвичи могли покупать хлеб самостоятельно. Если учесть, что население столицы по численности равнялось численности войск целого фронта, то выйдет, что, помимо армий Западного фронта в Белоруссии, Центральное Черноземье снабжало еще и «второй фронт»- Москву.

Деревня Центральной России до революции не обнаруживала явных признаков кризиса даже в промышленном Подмосковье [Ковалев, 2004, с. 128]. После революции ситуация лишь ухудшалась, что накладывало дополнительные обязательства по продовольственным поставкам на черноземные губернии. Следовательно, весь военный период, в том числе и в 1917 г., Центрально-Черноземный район выступал как один из основных источников по закупкам продовольствия для фронта, так и ведущий поставщик хлебной продукции в промышленные губернии центра страны. Значение продовольственных заготовок в Центральном Черноземье заключалось в том, что они не только давали хлеб армии, но и закрывали задачу снабжения промышленного центра империи.

\section{Список литературы}

1. Алехина Е.В., Есиков С.А., Старостин М.Е., Хорошун К.Ю., Щербинин П.П., Щербинина Ю.В., 2010. Земство и кооперативное движение в Тамбовской губернии в период Первой мировой войны 1914-1918 гг. Российский крестьянин в годы войн и в мирные годы. Тамбов: 96-101.

2. Анфимов А.М., 1962. Российская деревня в годы первой мировой войны (1914 - февраль 1917 г.). М., Соцэкгиз, 383.

3. Безгин В.Б. 2004. Крестьянская повседневность (традиции конца XIX - начала ХХ века). М. - Тамбов, 303.

4. Дихтяр Г.А. 1960. Внутренняя торговля в дореволюционной России. АН СССР. М., 237.

5. Иванов А.А. 2002. Сельскохозяйственное производство в черноземной деревне в годы Первой мировой войны (по материалам Тамбовской губернии). Бартеневские чтения: Материалы II региональной научной конференции, посвященной 140-летию отмены крепостного права в России. Липецк: 129-139.

6. Ковалев Д.В. 2004. Аграрные преобразования и крестьянство столичного региона в первой четверти XX века (по материалам Московской губернии). М., МПГУ, 305.

7. Кондратьев Н.Д. 1993. Особое мнение. Избранные произведения в 2-х книгах. Кн. 1. М., Наука, 654.

8. Курская губерния и куряне в Первой мировой войне: Курский военно-исторический сборник. 2014. Вып. 14. Курск, 100.

9. Люкшин Д.И. 2013. Аграрный саботаж лета 1917 г. - пролог общинной революции. Государственная власть и крестьянство в XIX - начале XXI века: сборник статей. Коломна, МГОСГИ, 180. 
10. Магомедов Р.Р., Гришакова Л.В. 2012. Война и хлеб. История продовольственной политики государства на Южном Урале в годы Первой мировой войны. Оренбург, ОГПУ, 171.

11. Мацузато К. 1997. «Общественная ссыпка» и военно-продовольственная система России в годы Первой мировой войны. Крестьяноведение. Теория. История. Современность. Ежегодник. 1997. Москва: 147-176.

12. Нефедов С.А. 2005. Февраль 1917 года: власть, общество, хлеб и революция. Уральский исторический вестник. № 10-11. (Власть и общество в российской провинции). Екатеринбург: 112-126.

13. Нефедов С.А. 2010. История России. Факторный анализ. Т. II: От окончания Смуты до Февральской революции. Территория будущего. М., 685.

14. Островский А.В. 1999. Государственно-капиталистические и кооперативные тенденции в экономике России: 1914-1917 гг. Россия и Первая мировая война (Материалы международного научного коллоквиума). СПб.: 482-496.

15. Островский А.В. 2013. Зерновое производство Европейской России в конце XIX начале XX в. СПб., Полторак, 414.

16. Островский А.В. 2014. Животноводство Европейской России в конце XIX - начале ХХ в. СПб., Полторак, 441.

17. Петровичева Е.М. 2001. Земства Центральной России в период первой мировой войны. М., МПГУ,125.

18. Роднов М.И. 2012. Пространство хлебного рынка (Уфимская губерния в конце XIX начале XX вв.). Уфа, ДизайнПресс, 224.

19. Самохин К.В. 2002. Мобилизации, реквизиции и заготовки для армии в Тамбовской губернии в период Первой мировой войны. Социальная история российской провинции в контексте модернизации аграрного общества в XVIII-XX вв. Тамбов.

20. Тагирова Н.Ф. 2014. Хлебная торговля в России 1914-1917 гг.: коллизии рыночного и государственного регулирования. Россия и Первая мировая война: экономические проблемы, общественные настроения, международные отношения. М.: 62-75.

21. Томпстон С.-Р. 2008. Российская внешняя торговля XIX - начала XX в.: организация и финансирование. М., РОССПЭН, 470.

22. Хрящева А. 1921. Крестьянство в войне и революции. Статистико-экономические очерки. М., 45.

\section{References}

1. Alekhina E.V., Esikov S.A., Starostin M.E., Horoshun K.Yu., Shcherbinin P.P., Shcherbinina Yu.V., 2010. Zemstvo i kooperativnoe dvizhenie v Tambovskoj gubernii v period Pervoj mirovoj vojny 1914-1918 gg. Rossijskij krest'yanin v gody vojn i v mirnye gody [Zemstvo and cooperative movement in the Tambov province during the First world war 1914-1918 Russian peasant during the years of wars and in years of peace]. Tambov: 96-101.

2. Anfimov A.M., 1962. Rossijskaya derevnya v gody Pervoj mirovoj vojny (1914 - fevral' 1917 g.) [Russian village during the First World War (1914 - February 1917)]. M., Socekgiz, 383.

3. Bezgin V.B. 2004. Krest'yanskaya povsednevnost' (tradicii konca XIX - nachala XX veka) [Peasant everyday life (traditions of the late XIX - early XX century)]. M. - Tambov, 303.

4. Dihtyar G.A. 1960. Vnutrennyaya torgovlya v dorevolyucionnoj Rossii [Domestic trade in pre-revolutionary Russia]. M., AN SSSR, 237.

5. Ivanov A.A. 2002. Sel'skohozyajstvennoe proizvodstvo $\mathrm{v}$ chernozemnoj derevne $\mathrm{v}$ gody Pervoj mirovoj vojny (po materialam Tambovskoj gubernii) [Agricultural production in a black earth village during the First World War (based on materials from the Tambov province)]. Bartenevskie chteniya: Materialy II regional'noj nauchnoj konferencii, posvyashchennoj 140-letiyu otmeny krepostnogo prava v Rossii. Lipeck: 129-139.

6. Kovalev D.V. 2004. Agrarnye preobrazovaniya i krest'yanstvo stolichnogo regiona v pervoj chetverti XX veka (po materialam Moskovskoj gubernii) [Agrarian transformations and the peasantry of the capital region in the first quarter of the XX century (based on the materials of the Moscow province)]. M., MPGU, 305.

7. Kondrat'ev N.D. 1993. Osoboe mnenie [Dissenting opinion]. Izbrannye proizvedeniya v 2-h knigah. Kn. 1. M., Nauka, 654. 
8. Kurskaya guberniya i kuryane v Pervoj mirovoj vojne: Kurskij voenno-istoricheskij sbornik [Kursk province and kuryans in the First World War: Kursk military-historical collection]. 2014. Vyp. 14. Kursk, 100.

9. Lyukshin D.I. 2013. Agrarnyj sabotazh leta 1917 g. - prolog obshchinnoj revolyucii. Gosudarstvennaya vlast' i krest'yanstvo v XIX - nachale XXI veka: sbornik statej [Agrarian sabotage of the summer of 1917 - the prologue to the communal revolution. State power and the peasantry in the XIX - early XXI century: a collection of articles]. Kolomna, MGOSGI, 180.

10. Magomedov R.R., Grishakova L.V. 2012. Vojna i hleb. Istoriya prodovol'stvennoj politiki gosudarstva na Yuzhnom Urale v gody Pervoj mirovoj vojny [War and bread. The history of the food policy of the state in the South Urals during the First World War]. Orenburg, OGPU, 171.

11. Macuzato K. 1997. «Obshchestvennaya ssypka» i voenno-prodovol'stvennaya sistema Rossii v gody Pervoj mirovoj vojny [«Public loading» and the military-food system of Russia during the First World War]. Krest'yanovedenie. Teoriya. Istoriya. Sovremennost'. Ezhegodnik. 1997. M.: 147-176.

12. Nefedov S.A. 2005. Fevral' 1917 goda: vlast', obshchestvo, hleb i revolyuciya [February 1917: Power, Society, Bread and Revolution]. Ural'skij istoricheskij vestnik. № 10-11. (Vlast' i obshchestvo v rossijskoj provincii). Ekaterinburg: 112-126.

13. Nefedov S.A. 2010. Istoriya Rossii. Faktornyj analiz [History of Russia. Factor analysis]. T. II: Ot okonchaniya Smuty do Fevral'skoj revolyucii. Territoriya budushchego. M., 685.

14. Ostrovskij A.V. 1999. Gosudarstvenno-kapitalisticheskie i kooperativnye tendencii v ekonomike Rossii: 1914-1917 gg. [State-Capitalist and Cooperative Trends in the Russian Economy: 1914-1917] Rossiya i Pervaya mirovaya vojna (Materialy mezhdunarodnogo nauchnogo kollokviuma). SPb.: 482-496.

15. Ostrovskij A.V. 2013. Zernovoe proizvodstvo Evropejskoj Rossii v konce XIX - nachale XX v. [Grain production of European Russia in the late XIX - early XX century] SPb., Poltorak, 414.

16. Ostrovskij A.V. 2014. Zhivotnovodstvo Evropejskoj Rossii v konce XIX - nachale XX v. [Animal husbandry in European Russia in the late XIX - early XX century] SPb., Poltorak, 441.

17. Petrovicheva E.M. 2001. Zemstva Central'noj Rossii v period pervoj mirovoj vojny [Zemstvos of Central Russia during the First World War]. M., MPGU, 125.

18. Rodnov M.I. 2012. Prostranstvo hlebnogo rynka (Ufimskaya guberniya v konce XIX nachale XX vv.) [Space of the grain market (Ufa province in the late 19th - early 20th centuries)]. Ufa, DizajnPress, 224.

19. Samohin K.V. 2002. Mobilizacii, rekvizicii i zagotovki dlya armii v Tambovskoj gubernii v period Pervoj mirovoj vojny [Mobilization of requisition and procurement for the army in the Tambov province during the First World War]. Social'naya istoriya rossijskoj provincii v kontekste modernizacii agrarnogo obshchestva v XVIII-XX vv. Tambov.

20. Tagirova N.F. 2014. Hlebnaya torgovlya v Rossii 1914-1917gg.: kollizii rynochnogo i gosudarstvennogo regulirovaniya [Bread trade in Russia 1914-1917: collisions of market and state regulation]. Rossiya i Pervaya mirovaya vojna: ekonomicheskie problemy, obshchestvennye nastroeniya, mezhdunarodnye otnosheniya. M.: 62-75.

21. Tompston S.-R. 2008. Rossijskaya vneshnyaya torgovlya XIX - nachala XX v.: organizaciya i finansirovanie [Russian foreign trade of the XIX - early XX centuries: organization and financing]. M., ROSSPEN, 470.

22. Hryashcheva A. 1921. Krest'yanstvo v vojne i revolyucii [The peasantry in the war and revolution. Statistical and economic essays]. Statistiko-ekonomicheskie ocherki. M., 45.

Конфликт интересов: о потенциальном конфликте интересов не сообщалось.

Conflict of interest: no potential conflict of interest related to this article was reported.

\section{ИНФОРМАЦИЯ ОБ АВТОРЕ}

Оськин Максим Викторович, доктор исторических наук, профессор кафедры философии, истории и теории государства и права Международной полицейской академии ВПА, г. Тула, Россия

\section{INFORMATION ABOUT THE AUTHOR}

Maxim V. Os'kin, Doctor of Historical Sciences, Professor of the Department of Philosophy, History and Theory of State and Law, WPA International, Police Academy, Tula, Russia 